\title{
THE DEMOCRATIC CHALLENGE OF INCORPORATION: INTERNATIONAL HUMAN RIGHTS TREATIES AND NATIONAL CONSTITUTIONS
}

\author{
Joanna Harrington*
}

\begin{abstract}
According to Canadian Supreme Court Justice Claire L'Heureux-Dubé, the global judicial community is engaged in a process of dialogue, especially in cases involving the determination of constitutionally protected human rights. However, as this author notes, if there is a process of dialogue taking place, it does not always include the international treaty monitoring bodies supported by the United Nations, even when there is a treaty link between the international body and the domestic state. The author considers the approach taken by courts in South Africa, the United Kingdom and Ireland with respect to the judicial consideration of international human rights decisions, linking the prospects for dialogue to the express mandates to consider such case law within their constitutions, while contrasting the experience with that of Canada and New Zealand, where no such express imperative exists. The author concludes by suggesting that such a constitutionally-determined approach may well be the most democratic means of reconciling a state's international commitments with its domestic law.
\end{abstract}

\section{THE GLOBAL JUDICIAL DIALOGUE}

In 1999, Justice Claire L'Heureux-Dubé of the Supreme Court of Canada published a law review article in which she recognised "how growing international links and influences are affecting and changing judicial decisions, particularly at the level of top appellate courts throughout the world." She described this phenomenon as a form of globalisation that was taking place within the legal and judicial world, with "more and more courts, particularly within the common law world, ... looking

* Associate Professor, Faculty of Law, University of Alberta, Canada; former Parliamentary Legal Officer to Lord Lester of Herne Hill QC during the passage of the UK Human Rights Act 1998. Thanks are due to the Social Sciences and Humanities Research Council of Canada for its support for this research and its presentation in New Zealand, and to Alex Millman for footnote assistance.

1 Claire L'Heureux-Dubé "The Importance of Dialogue: Globalization and the International Impact of the Rehnquist Court" (1998-1999) 34 Tulsa LJ 15, 16. 
to the judgments of other jurisdictions, particularly when making decisions on human rights issues." ${ }^{2}$ To support her point, examples were drawn from cases in Australia, Canada, India, Namibia, New Zealand and South Africa to show that judges are looking to "a broad spectrum of sources in the law of human rights when deciding how to interpret their constitutions and deal with new problems," ${ }^{3}$ although they were in no way bound to follow the foreign authorities. Moreover, according to L'Heureux-Dubé, these judges were not simply receiving foreign law for application and adaptation, but were "to a greater and greater extent ... mutually reading and discussing each others' jurisprudence." 4 They were thus engaging in a process of dialogue within a global judicial community - views that echo those of Professor Anne-Marie Slaughter in her work on trans-judicial communications between courts around the world. ${ }^{5}$

Justice L'Heureux-Dubé clearly embraced this process of dialogue and interchange as innately good. In her view, the dialogue that resulted from the consideration of another jurisdiction's approach to a similar social problem or similarly-worded rights provision could only be beneficial. She also noted how courts in jurisdictions with newer constitutions could gain from the experience of courts with older instruments, with Canada serving as one example, having benefited from the accumulated wisdom of the American courts in the early days of the 1982 Canadian Charter of Rights and Freedoms. ${ }^{6}$

However, it is also true that many newer bills of rights take a decidedly different approach to that embraced by the United States Constitution, with many eschewing what is perceived as an absolute rights approach for limitation clauses expressly balancing individual rights with community interests. ${ }^{7}$ For these bills of rights, the corpus of international human rights law, with its similar approach of balance and limitation, might also provide useful guidance, particularly since there are, as acknowledged by L'Heureux-Dubé, "numerous genealogical 'links' between national human

2 Ibid.

3 Ibid, 21 (emphasis in the original).

4 Ibid (emphasis in the original).

5 Anne-Marie Slaughter "A Typology of Transjudicial Communication" (1994) 29 U Rich L Rev 99 [Slaughter "Transjudicial Communication"]. See also Anne-Marie Slaughter "Judicial Globalization" (19992000) 40 Va J Int'l L 1103 and Anne-Marie Slaughter "A Global Community of Courts" (2003) 44 Harv Int'l LJ 191.

6 See further Christopher Manfredi "The Canadian Supreme Court and American Judicial Review: United States Constitutional Jurisprudence and the Canadian Charter of Rights and Freedoms" (1992) 40 Am J Comp L 213, Gérard V LaForest "The Use of American Precedents in Canadian Courts" (1994) 46 Melbourne L Rev 211, and Peter McCormick "The Supreme Court of Canada and American Citations 19451994: A Statistical Overview" (1997) 8 Sup Ct L Rev 52.

7 This balancing approach, and the normative analysis it entails, may also explain the Supreme Court of Canada's greater openness to the use of foreign law than the U.S. Supreme Court: see Sarah K Harding "Comparative Reasoning and Judicial Review" (2003) 28 Yale J Int'l Law 409, 427-32. 
rights guarantees and international human rights documents." 8 These links have in fact led to citations in Canadian cases to the jurisprudence of the (non-binding) European Commission and (binding) European Court of Human Rights, albeit as a kind of comparative foreign law rather than as a source for determining the content of international law obligations. ${ }^{9}$ Nevertheless, according to L'Heureux-Dubé, these "links to international law help form a kind of 'common denominator' of understanding for judges interpreting national or regional human rights documents" and she further acknowledged that "international standards are often used as interpretive aids for domestic constitutional law."10 (Justice L'Heureux-Dubé would later add, by way of her majority opinion in the well-known deportation case of Baker $v$ Canada that "the values reflected in international human rights law may help inform the contextual approach to statutory interpretation and judicial review,"11 invoking in support a case from the New Zealand Court of Appeal ${ }^{12}$ and another from the Supreme Court of India. ${ }^{13}$ )

In concluding her article, L'Heureux-Dubé $\mathrm{J}$ turned her attention to what she described as the "failure of the United States Supreme Court to take part in the international dialogue among the courts of the world, particularly on human rights issues," believing this failure to be a contributing factor in what she perceived to be that Court's "growing isolation and diminished influence." 14 She complained that the Rehnquist Court, "on human rights issues," had "referred to Canadian Supreme Court judgments only twice,"15 and continuing the equation of foreign decisions with those of an international tribunal, she also admonished the United States Supreme Court for never having referred to any decisions of the European Court or Commission of Human Rights. ${ }^{16}$ "In short," concluded L'Heureux-Dubé, "the United States Supreme Court is not a participant in the

8 L'Heureux-Dubé, above n 1, 24

9 On the blurring of the distinction between international and foreign law, and the benefits that may be gained by treating international law as foreign law, see Karen Knop "Here and There: International Law in Domestic Courts" (1999-2000) 32 N Y U J Int'l L \& Pol 501, 525-36.

10 L'Heureux-Dubé, above n 1, 24-25.

11 Baker v Canada (Minister of Citizenship and Immigration) [1999] 2 SCR 817, para 70 L'Heureux-Dubé.

12 Tavita $v$ Minister of Immigration [1994] 2 NZLR 257 (CA) Cooke P, but without reference to the subsequent case of Puli'uvea v Removal Review Authority (1996) 2 HRNZ 510 (CA) Keith J.

13 Vishaka v Rajasthan [1997] 3 LRC 361 (SC India) Virma CJ.

14 L'Heureux-Dubé, above n 1,37.

15 Ibid. A later search (unrestricted to human rights cases and covering a ten-year period) found ten US Supreme Court cases making a "passing" reference to Canadian law, four referring to Australian law, and two referring to New Zealand law: Harding, above n 7, 420

16 Reference has since been made to Dudgeon v United Kingdom (1982) 4 EHRR 149 in Lawrence v Texas (2003) 539 US 558 Kennedy J. 
international dialogue about human rights"17 because it did not refer in its judgments to the decisions of foreign courts, nor "the various decisions written by United Nations and European human rights decision-making bodies." 18

It is this last comment on which I wish to focus my contribution to these proceedings. Professor Slaughter has observed that judicial cross-fertilisation of ideas has taken place even when "[n]either the speaking nor the listening court is bound by a treaty structure or any other direct and formal links." ${ }^{19}$ My interest, however, is in precisely the situation where there is a treaty structure in place, as well as direct links by State consent, and yet no dialogue. I begin by noting the irony of L'Heureux-Dubé J's admonishment of the United States Supreme Court, given that the Supreme Court of Canada rarely mentions in its judgments the jurisprudence of the United Nations human rights treaty monitoring bodies, even when (or perhaps precisely because) that jurisprudence has involved concrete cases from Canada. ${ }^{20}$ Others have also noted the "muddled enthusiasm" Canadian case law displays for international law, ${ }^{21}$ and yet assurances are given by members of the Court that: "We do not confine ourselves to polite references to the international agreements themselves, but examine with care the interpretations given to them by international institutions and domestic courts of many countries, as well as in the writings of learned authors ..."22

But putting aside the complaint about "doing as I say rather than as I do" as well as the obvious rebuttal that perhaps these bodies offer nothing worth citing, it is striking to note that Justice L'Heureux-Dubé makes no comment about the democratic concerns underlying a supreme court's citation of "foreign law", especially the "law" of an international tribunal acting in essence as a kind of international (albeit legally ineffectual) final court of appeal for litigants who have exhausted their domestic remedies. Within Canada, such democratic concerns have clearly emerged, with Canadian Supreme Court Justice Louis LeBel, writing extra-judicially with Gloria Chao, arguing that "at the heart of the debate" provoked by the domestic court's interpretation or application of international law "is the tension between the democratic principle underlying the internal legal order

17 L'Heureux-Dubé, above n 1, 38.

18 Ibid, 40.

19 Slaughter "Transjudicial Communication", above n 5, 118

20 See further, Joanna Harrington "The Absent Dialogue: Extradition and the International Covenant on Civil and Political Rights" (2006) 32 Queen's LJ 82.

21 Knop, above n 9, 515, citing in support Anne F Bayefsky, "International Human Rights Law in Canadian Courts" in Benedetto Conforti and Francesco Francioni (eds) Enforcing International Human Rights in Domestic Courts (London: Martinus Nijhoff, 1997) 295, 325.

22 Gérard V La Forest, "The Expanding Role of the Supreme Court of Canada in International Law Issues" (1996) 34 Can Ybk Int'l L 89, 98 (emphasis added). 
and the search for conformity or consistency with a developing and uncertain external order."23 Similar democratic concerns also underpinned the dissenters' views in Baker v Canada concerning the judicial use of the values of a ratified but unimplemented human rights treaty. ${ }^{24}$

It may also be the case that a national supreme court with the constitutional responsibility for providing the "last word" may well be concerned about the appearance, if not the sensibilities, of appearing to cede sovereignty to an international adjudicative body - even one to which the state has given its consent as in the case of Canada and the Human Rights Committee, the Committee Against Torture, and the Committee on the Elimination of Discrimination Against Women. (Litigants in Canada can also proceed to the Inter-American Commission on Human Rights.) A supreme court's sense of being supreme, even if fallible, is often perceived as a goal worthy of protection for the very coherence of the domestic legal system and a top appellate court may be wary of sending a mixed message with respect to the domestic standing of an international tribunal's decision. Perhaps the engagement with the "foreign law" that is not so foreign would undermine the stabilising role of precedent in the domestic legal system? Perhaps too, a court that has gained its role as "the Supreme Court" as a result of a deliberate break with a colonial past is obliged to avoid even the appearance of subservience to an international body? And lastly, there is the argument that silence may be the constitutionally correct response in the absence of any provision requiring a supreme court to consider the virtues of international and foreign law, with this last point leading to the following discussion of the means used by some states to encourage the "international dialogue" to which L'Heureux-Dubé J subscribes.

\section{THE EXPRESS OBLIGATION TO CONSIDER INTERNATIONAL CASE $\boldsymbol{L A W}$}

As is well known, there are national constitutions that oblige domestic courts, including final courts of appeal, to recognise and consider international law in interpreting a domestic bill of rights. In determining what constitutes international law for this purpose, the obvious starting point is the list of international law sources recognised as such by the international community through state adherence to the Statute of the International Court of Justice. Article 38(1)(a) of the Statute identifies conventions (in the sense of treaties), custom, and general principles as the main sources of international law, with judicial decisions and the writings of highly qualified publicists being

23 Louis LeBel and Gloria Chao "The Rise of International Law in Canadian Constitutional Litigation: Fugue or Fusion? Recent Developments and Challenges in Internalizing International Law" (2002) 16 Sup Ct L $\operatorname{Rev}(2 \mathrm{~d}) 23,24$.

24 Baker v Canada, above n 11, paras 79-80 Iacobucci J. I have argued elsewhere for a greater role for Parliament in the making of treaties as a means to address this concern: see Joanna Harrington "Redressing the Democratic Deficit in Treaty Law Making: (Re)Establishing a Role for Parliament" (2005) 50 McGill LJ 465 . 
listed as supplementary sources. While widely recognised as the starting point for any discussion of the sources of international law, ${ }^{25}$ Article $38(1)$ is not worded so as to be exhaustive on the topic.

In the field of international human rights law, with its creation by treaty of various international tribunals to receive and determine specific human rights complaints, it can be argued that any "obligation to consider" international law must also extend, as a matter of good faith, to the associated international case law that these complaints procedures produce. This jurisprudence is issued by the treaty-monitoring bodies to guide states as to the content and implementation of their treaty obligations, and its purpose is not defeated by the recommendatory nature of the resulting views. A state's obligation of good faith with respect to its treaty obligations must surely include, at the very least, the consideration of the end product of the complaint process as created by those treaties. Such consideration may also assist in ensuring a degree of congruence between the treaty's creation of the international body and the decisions that this body makes to guide a state's implementation of its treaty obligations.

\section{A The South African Model}

South Africa's current constitutional order provides a clear example of an express obligation to consider international law in human rights cases. Under section 35(1) of the Interim Constitution of $1993,{ }^{26}$ (negotiated by a representative, but unelected, multi-party body which then established an elected Constitutional Assembly to produce the "final" Constitution), the South African courts were directed to "have regard to public international law applicable to the protection of the rights entrenched" in the South African Bill of Rights. This obligation was retained in the final Constitution of $1996,{ }^{27}$ with some revisions. Section 39(1) provides that: "When interpreting the Bill of Rights, a court, tribunal or forum (a) must promote the values that underlie an open and democratic society based on human dignity, equality and freedom; (b) must consider international law; and (c) may consider foreign law."

Thus the text of the South African Constitution expressly "affirms that international law is an important interpretive tool,"28 with democratic South Africa's re-admission to the international community being the likely rationale for its "constitutional acknowledgement of the importance of both international law and international human rights." ${ }^{29}$ As for the content of this obligation,

25 See, for example Ian Brownlie Principles of Public International Law (6ed, Oxford University Press, Oxford, 2003), 4-5.

26 Interim Constitution of the Republic of South Africa Act 1993 (in force 27 April 1994)

27 Constitution of the Republic of South Africa Act 1996 (in force 4 February 1997).

28 Christian Education South Africa v Minister of Education 2000 (10) BCLR 1051, para 13, fn 8 (S Afr Const $\mathrm{Ct}$ ).

29 Kaunda v President of the Republic of South Africa (No 2) 2004 (10) BCLR 1009, para 223 (S Afr Const $\mathrm{Ct}$ ). 
almost from the beginning the South African Constitutional Court has interpreted the constitutional directive to consider international law as applying to both "non-binding as well as binding law,"30 including the non-binding decisions of several international human rights bodies. According to the Constitutional Court, these decisions may be used as "tools of interpretation"31 with respect to the Bill of Rights, with the Court explaining that: ${ }^{32}$

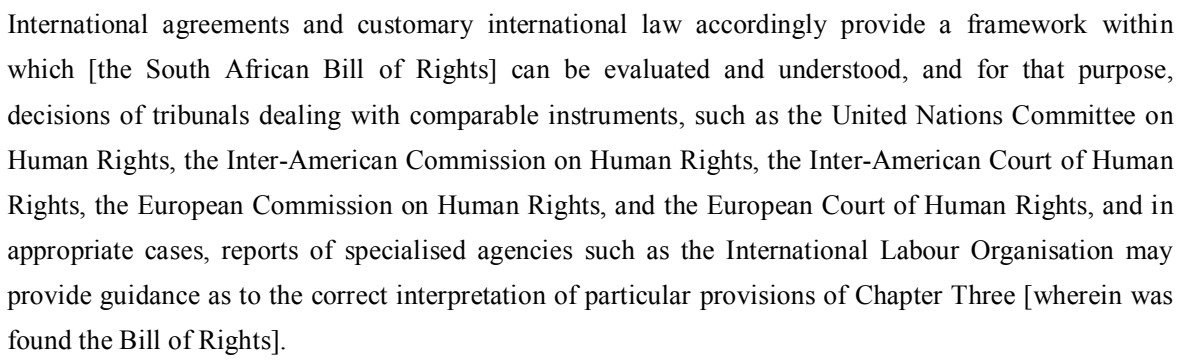

However, the South African courts are also clearly of the view that they are not bound to follow this "guidance", especially when the recognition of rights within the national constitution extends beyond that recognised by international law. Support for this position is found in the Constitutional Court's decision concerning same-sex marriage. ${ }^{33}$ In support of its contention that the exclusion of same-sex couples from the institution of marriage was not to be regarded as unfair discrimination, the South African government had argued that international law recognises and protects heterosexual marriage only, invoking in support the text of the Universal Declaration of Human Rights $^{34}$ as well as the Joslin decision of the UN Human Rights Committee concerning a failed challenge to a New Zealand law denying marriage licences to same-sex couples. ${ }^{35}$ While reliance on the 1948 Declaration was readily dismissed on the basis that views had since evolved, ${ }^{36}$ Sachs J both engaged with, and expressly distinguished, the Joslin decision, explaining that the Committee's holding "that there was no provision in the [relevant human rights treaty] which forbade discrimination on sexual orientation" was "a far cry from declaring that the [treaty] forbids the

30 State v Makwanyane 1995 (3) SA 391; 1995 (6) BCLR 665, para 35 (S Afr Const Ct) Chaskalson CJ.

31 Ibid.

32 Ibid

33 Minister of Home Affairs v Fourie; Lesbian and Gay Equality Project v Minister of Home Affairs 2006 (3) BCLR 355 (S Afr Const Ct) [Fourie].

34 UNGA Resolution 217 (10 December 1948) A/RES/3/217, 71.

35 Joslin v New Zealand (17 July 2002) CCPR/C/75/D/902/1999 (UNHRC); Human Rights Committee "Report of the Human Rights Committee" (30 October 2002) A/57/40 (vol II) 214.

36 Fourie, above n 33, para 102. 
recognition of same-sex marriage ... . ${ }^{137}$ Moreover, according to Sachs J, the Constitution explicitly proclaims the anti-discriminatory right which was held to lack support from the text of the treaty, thus concluding that "discrimination on the grounds of sexual orientation is expressly stated by [the South African] Constitution to be presumptively unfair." 38

As for the use of foreign law sources by domestic courts, both the interim and current constitutions of South Africa expressly provide for its possible consideration, although on a permissive rather than mandatory basis. Section 35(1) of the Interim Constitution provided that the courts "may have regard to comparable foreign case law" while section 39(1)(c) of the current Constitution simply states that the courts "may consider foreign law." Nonetheless, in interpreting its constitutional obligations, the South African Constitutional Court has made clear that its ultimate responsibility is "to construe the South African Constitution, and not an international instrument or the constitution of some foreign country."39 "Due regard" must thus be paid, according to the Court, to South Africa's legal system, history and circumstances, as well as the structure and language of South Africa's constitutional instrument. ${ }^{40}$ International and foreign case law may provide assistance to the domestic courts through a constitutional "obligation to consider", but the South African courts have made it clear that they "are in no way bound to follow it." 41

\section{$B$ The British Experience}

A similar openness to the citation of international law sources can be found in Europe, although its breadth is limited to regional international law given that the citation is directly linked to the project of incorporation of the European Convention on Human Rights. ${ }^{42}$ National incorporation is viewed by European states as serving an essential role in ensuring the treaty regime's continuing effectiveness, especially given the regime's expansion and rising caseloads at the international level. ${ }^{43}$ As a result, both the United Kingdom and Ireland have enacted statutory bills of rights requiring their higher courts to consider the decisions of the European bodies created by the Convention. This includes the jurisprudence of the European Court of Human Rights as well as the decisions and reports of the now-abolished European Commission on Human Rights (which, unlike

37 Ibid, para 103.

38 Ibid.

39 State v Makwanyane, above n 30, para 39 Chaskalson P.

40 Ibid.

41 Ibid.

42 Convention for the Protection of Human Rights and Fundamental Freedoms (4 November 1950) 213 UNTS 221, ETS No 5 (commonly called the European Convention on Human Rights) [ECHR].

43 See further Explanatory Report on Protocol No 14 to the Convention for the Protection of Human Rights and Fundamental Freedoms, Amending the Control System of the Convention (Council of Europe, Strasbourg, 2004). 
the Court, never had the power to issue binding judgments). Some may question whether the Commission should be treated as a source of law in this way, but given its recommendatory authority, its inclusion opens the door to asking why, in general, other international human rights bodies, acting in an adjudicative fashion but without the power to issue binding judgments, should not be similarly cited as persuasive authority with regards to their associated international instrument.

Britain's Human Rights Act 1998 (HRA) is a statutory bill of rights with the stated purpose of giving "further effect" under British law to the rights and freedoms guaranteed by the European Convention on Human Rights. ${ }^{44}$ These rights are ones which Britain has long been obliged to protect as a matter of international law, but which could not be litigated in a British court until the Convention was transformed into a domestic law obligation. With the enactment of the HRA, Britain incorporated the Convention and also gained a statutory bill of rights, with the legislative scheme being one that encourages some degree of dialogue between the British courts and the European Court of Human Rights, since nothing in the HRA removes the right of international petition guaranteed by the Convention to litigants with admissible claims who have exhausted their domestic options for redress. ${ }^{45}$

According to the HRA, British courts are now obliged to "take into account" the jurisprudence of the European Court of Human Rights, and for that matter, the entire corpus of human rights jurisprudence within this particular international human rights regime, as first established since the days of the European Commission on Human Rights. Section 2(1) of the HRA requires the British courts to "take into account" any judgment, decision, declaration or advisory opinion of the European organs "whenever made or given, so far as, in the opinion of the court or tribunal, it is relevant to the proceedings in which that question has arisen." 46 While this stops short of making the European views binding on British courts, the obligation to "take into account" clearly means more than having mere regard. It thus opens the door to some degree of judicial dialogue between the international and national courts, especially when one acknowledges the obligation imposed on the

44 Human Rights Act 1998, c 42, preamble [HRA].

45 See further, Joanna Harrington "The British Approach to Interpretation and Deference in Rights Adjudication" (2004) 23 Sup Ct L Rev (2d) 269-303, reprinted in Grant Huscroft and Ian Brodie (eds) Constitutionalism in the Charter Era (LexisNexis, Toronto, 2004) 269-303.

46 See further, Merris Amos Human Rights Law (Hart, Oxford, 2006) 17-23; Roger Masterman "Section 2(1) of the Human Rights Act 1998: Binding Domestic Courts to Strasbourg?" [2004] PL 725; Roger Masterman "Taking the Strasbourg Jurisprudence into Account: Developing a 'Municipal Law of Human Rights' under the Human Rights Act" (2005) 54 ICLQ 907 [Masterman "A Municipal Law of Human Rights"]; Elizabeth Wicks "Taking Account of Strasbourg? The British Judiciary's Approach to Interpreting Convention Rights" (2005) 11 Eur PL 405. 
British courts by section 6 of the HRA to act compatibly with Convention rights ${ }^{47}$ - an obligation not found in South Africa. "Take into account" could therefore mean "must follow" if the courts were to conflate the distinction between consistency with Convention rights and consistency with their related jurisprudence.

In the early days of the HRA, it was presumed (or desired) that this street of dialogue would run both ways, with both legislators and judges suggesting that a well-reasoned British decision could serve to influence the European Court and thus contribute to the growth of Convention jurisprudence as a whole. ${ }^{48}$ As suggested by the Lord Chancellor during the Act's passage through Parliament, the British "courts must be free to try to give a lead to Europe as well as to be led."49 Several commentators agreed, suggesting that the British courts could go further than the European organs in their interpretations of Convention rights, provided they did not rob other Convention rights of their content. ${ }^{50}$ Others suggested that it was open to the British courts "to consider, but disapply a particular decision," ${ }^{51}$ such as a decision that "compelled a conclusion fundamentally at odds with ... the British Constitution." 52

But the prospects for divergence resulting from a judicial dialogue mandated by section 2(1) of the HRA have since been limited by the self-restraint of the British courts, working within the presumed dictates of Parliament's chosen model for incorporation. Taking into account that the purpose of the HRA was "to bring rights home", the Judicial Committee of the House of Lords has suggested that in the absence of special circumstances, British courts should follow the jurisprudence of the European Court at least where it is "clear and constant." 53 British courts, while not bound by the European jurisprudence, should also follow what the European Court has said if its

47 Section 6 of the HRA makes it "unlawful for a public authority to act in a way which is incompatible with a Convention right" while section 6(3)(a) expressly extends this obligation to "a court or tribunal".

48 See $R$ (Alconbury Developments Ltd) v Secretary of State for the Environment, Transport and the Regions [2001] UKHL 23; [2003] 2 AC 295, para 63 Lord Nolan [Alconbury]. See also Lord Hope of Craighead "Human Rights - Where Are We Now" [2000] 5 EHRLR 439, 446.

49 (18 November 1997) 583 HLD col 515.

50 See Francesca Klug "The Human Rights Act - A 'Third Way' or a 'Third Wave' Bill of Rights" [2001] 4 EHRLR 361, 370; David Bonner and others "Judicial Approaches to the Human Rights Act" (2003) 52 ICLQ 549, 552-53. For recent espousal, see Masterman "A Municipal Law of Human Rights," above n 46.

51 Helen Fenwick Human Rights and Civil Liberties (3 ed, Cavendish, London, 2002), 146-47.

52 Alconbury, above n 48, para 76 Lord Hoffmann.

53 Ibid, para 26 Lord Slynn of Hadley, cited with approval in $R$ (Anderson) $v$ Secretary of State for the Home Department [2002] UKHL 46; [2003] 1 AC 837, para 18 Lord Bingham of Cornhill [Anderson] and $R$ (Ullah) v Special Adjudicator [2004] UKHL 26; [2004] 2 AC 323, para 20 Lord Bingham of Cornhill [Ullah]. 
jurisprudence lays down certain "minimum threshold requirements" 54 and British courts should not without good reason depart from the principles laid down in a carefully considered judgment of the European Court's Grand Chamber ${ }^{55}$ - a 17 -member body used only for cases raising a serious question affecting the interpretation of the Convention or where the resolution of a question might have a result inconsistent with a previous judgment of the Court. ${ }^{56}$ The Court of Appeal has also held, in connection with an attempt by counsel to discredit an unfavourable (and non-binding) Commission decision, that the British court "must tread very carefully even where it thinks that the rulings by the [European] court or commission may eventually prove to have been mistaken." ${ }^{\text {7 } 7}$

The rationale for such restraint is that since the reason for enacting the HRA was to bring rights home, "[t]hat purpose would not be achieved if the domestic courts were to depart in material respects from current thinking about the content of the Convention rights in Strasbourg"58 (the location of the European organs). This suggests that while deviation is permissible, it must occur at the margins or in areas where the Convention's jurisprudence is lacking. A year later, in the asylum case of $R$ (Ullah) $v$ Special Adjudicator concerning a failed attempt to extend the prohibition on deportation to face ill-treatment to future violations of religious freedom rights, Lord Bingham of Cornhill explained that the reason for following the "clear and constant jurisprudence" of the European regime rests on "the fact the Convention is an international instrument, the correct interpretation of which can be authoritatively expounded only by the Strasbourg court." 59 It follows, according to Lord Bingham, "that a national court subject to a duty such as that imposed by section 2 should not without strong reason dilute or weaken the effect of the Strasbourg case law," adding that "[i]t is indeed unlawful under section 6 of the 1998 Act for a public authority, including a court, to act in a way which is incompatible with a Convention right." 60 However, in an implicit response to the prospect of a British court going further than the European jurisprudence in its interpretation of a Convention right, Lord Bingham added that: ${ }^{61}$

$54 R$ (Amin) $v$ Secretary of State for the Home Department [2003] UKHL 51; [2004] 1 AC 653, para 44 Lord Bingham of Cornhill.

55 Anderson, above n 53, para 18 Lord Bingham of Cornhill.

56 ECHR, above $\mathrm{n} 42$, arts 27,30 and 43.

$57 R$ (Williamson and Others) $v$ Secretary of State for Education and Employment [2002] EWCA Civ 1926; [2003] QB 1300, para 37 (CA) Buxton LJ.

58 Attorney-General's Reference No 2 of 2001 [2003] UKHL 68; [2004] 2 AC 72, para 52 Lord Hope of Craighead.

59 Ullah, above n 53, para 20 Lord Bingham of Cornhill.

60 Ibid.

61 Ibid. 
It is of course open to member states to provide for rights more generous than those guaranteed by the Convention, but such provision should not be the product of interpretation of the Convention by national courts, since the meaning of the Convention should be uniform throughout the States party to it. The duty of national courts is to keep pace with the Strasbourg jurisprudence as it evolves over time: no more, but certainly no less.

Lord Bingham's position has since been endorsed by Lord Hope of Craighead in the asylum case of $N v$ Secretary of State for the Home Department, ${ }^{62}$ concerning the return to Uganda of a woman with AIDS whose condition had greatly improved due to medical treatment received in the United Kingdom. Recognising that the European case law required an "exceptional case" to bar the State from carrying out a planned deportation, Lord Hope embraced the above position and concluded that "[i]t is for the Strasbourg court, not for us, to decide whether its case law is out of touch with modern conditions and to determine what further extensions, if any, are needed to the rights guaranteed by the Convention." 63

This approach to the "taking into account" obligation under the HRA also works in tandem with Lord Bingham's earlier description generally of the judicial task under the new human rights scheme, a description worth reproducing in full: ${ }^{64}$

In interpreting the Convention, as any other treaty, it is generally to be assumed that the parties have included the terms which they wished to include and on which they were able to agree, omitting other terms which they did not wish to include or on which they were not able to agree. Thus particular regard must be had and reliance placed on the express terms of the Convention, which define the rights and freedoms which the contracting parties have undertaken to secure. This does not mean that nothing can be implied into the Convention. The language of the Convention is for the most part so general that some implication of terms is necessary, and the case law of the European court shows that the court has been willing to imply terms into the Convention when it was judged necessary or plainly right to do so. But the process of implication is one to be carried out with caution, if the risk is to be averted that the contracting parties may, by judicial interpretation, become bound by obligations which they did not expressly accept and might not have been willing to accept. As an important constitutional instrument the Convention is to be seen as a 'living tree capable of growth and expansion within its natural limits' (Edwards v Attorney General for Canada [1930] AC 124, 136 per Lord Sankey LC), but those limits will often call for very careful consideration.

$62 N v$ Secretary of State for the Home Department [2005] UKHL 31; [2005] 2 AC 296, para 24 [N] Lord Hope of Craighead.

63 Ibid, para 25 Lord Hope of Craighead.

64 Brown v Stott (Procurator Fiscal v Brown (Scotland)) [2003] 1 AC 682, 703, cited with approval in N, above n 62, para. 22 Lord Hope of Craighead. 
Thus, while the British courts now have an express mandate to cite European decisions in national human rights cases, the benefits for dialogue of such a mandate are limited by considerations of an institutional and democratic nature, reflecting a concern about the appropriate roles of the national and international court, even when directly linked by treaty and legislation. It is also an approach that can be reconciled with that taken by the South African Constitutional Court in the recent same-sex marriage case by the recognition that both courts are trying to respect the legislative intentions underlying their constitutional mandates to consider the international law. After all, the framers of their mandates went to some effort to give them guidance.

\section{The Irish Approach}

Ireland, interestingly, has followed suit, adding a statutory incorporation of the European Convention on Human Rights to a domestic legal regime with a pre-existing and long-established bill of rights with the status of supreme law. ${ }^{65}$ The Constitution of Ireland, or Bunreacht na hÉireann, was enacted in 1937 and remains the supreme law of Ireland. Any law or measure of the Irish State must comply with its provisions. ${ }^{66}$ While intended primarily as an instrument for the consolidation of independence, the Irish Constitution contains a few provisions on the protection of individual rights, the majority of which are found in Articles 40 to 44 under the heading "Fundamental Rights". These Articles recognise and protect the right to equality before the law; the right to personal liberty; the right to freedom of association, expression and assembly; and other rights relating to education, religion and the family. They thus serve as Ireland's bill of rights, with the further addition of Article 40.3.1 ${ }^{\circ}$ which provides: "The State guarantees in its laws to respect, and, as far as practicable, by its laws to defend and vindicate the personal rights of the citizen."

Since 1965, and the landmark judgment of Ryan v Attorney-General, ${ }^{67}$ the Irish Supreme Court has held that this broad but vaguely worded guarantee of protection for "personal rights" extends not only to those rights specifically enumerated in the constitution, but also to a number of "unspecified", "implied" or "unenumerated" rights, which have been left to be "discovered" by the Irish courts. ${ }^{68}$ These unspecified personal rights are wide-ranging in scope and add, for example, the right to bodily integrity, ${ }^{69}$ the right to marital privacy, ${ }^{70}$ and an express right to be presumed

65 European Convention on Human Rights Act 2003 (Eire) [ECHR Act].

66 Constitution of Ireland, art 15.4.

67 Ryan v Attorney-General [1965] IR 294 [Ryan].

68 See the judgment of Kenny J in Ryan, ibid, 312-13, which was subsequently endorsed by the Irish Supreme Court. On the Irish doctrine of unenumerated rights, see GW Hogan "Unenumerated Personal Rights: Ryan's Case Re-Evaluated" (1990-92) 25-27 Ir Jur NS 95.

69 The right at issue in Ryan, above $\mathrm{n} 67$.

70 McGee v Attorney-General [1974] IR 284. 
innocent ${ }^{71}$ to the protective fold of a constitution written in 1937. A helpful catalogue of the unenumerated rights "discovered" since 1965 can be found in the 1996 Report of the Constitution Review Group. ${ }^{72}$

The protection of "personal rights" also allows the Irish Constitution to contain a constantly evolving bill of rights, the malleability of which can provide a fruitful ground for challenging the acts and decisions of the Irish State given the robust power of judicial review accorded to Ireland's highest courts. ${ }^{73}$ It can also lead to rights colliding, with the Irish courts embracing a balancing or proportionality approach, but without a fixed set of criteria (or "Oakes test" to use the Canadian catch-phrase $^{74}$ ) for determining the appropriate balance.

It is also clear from this malleability that the Irish Constitution can easily protect the rights found in the European Convention on Human Rights, ${ }^{75}$ as well as those contained in other human rights treaties to which Ireland is a contracting party. But Ireland follows a strict dualist approach with respect to the domestic application of conventional international law, and because the Oireachtas $^{76}$ had (until recently) incorporated few human rights treaties into Irish law, their provisions could not be relied upon directly in an Irish court. This principle was expressly confirmed by the Irish Supreme Court in $1960,{ }^{77}$ ironically in a case that later went on to become the first decided case before the European Court of Human Rights. ${ }^{78}$

It is also a legal position that matched the general attitude of the Irish Bar and Bench, which traditionally did not refer to international instruments, nor to international decisions, in Irish legal proceedings. This attitude is well-illustrated in the decision of Finucane $v$ McMahon, ${ }^{79}$ which was published soon after the decision of the European Court of Human Rights in Soering v United Kingdom, ${ }^{80}$ but did not refer to it, despite the fact that both courts ruled that extradition could be refused where there was a probable risk that a fugitive's fundamental rights would not be adequately

71 Hardy v Ireland [1994] 2 IR 550.

72 Report of the Constitution Review Group (Stationery Office, Dublin, 1996) 246.

73 Constitution of Ireland, art 34.3.

$74 \quad R v$ Oakes [1986] 1 SCR 103.

75 ECHR, above $\mathrm{n} 42$.

76 The Oireachtas is the term used for the Irish Parliament as a whole, consisting of the President, a House of Representatives (Dáil Éireann), and a Senate (Seanad Éireann): Constitution of Ireland, Art 15.

77 In re Ó Laighléis [1960] IR 93, 125 Maguire CJ [Ó Laighléis].

78 Ibid (with its English spelling) became Lawless v Ireland (1979) 1 EHRR 15.

79 Finucane v McMahon [1990] IR 165 (Finucane).

80 Soering $v$ United Kingdom (1989) 11 EHRR 439. 
protected in the receiving state. This is all the more surprising when one realises that Supreme Court Justice Brian Walsh took part in both decisions, being the Irish Judge on what was then a part-time European Court of Human Rights. On the other hand, perhaps this fact suggests a conscious decision on the part of Justice Walsh not to confuse his work in one jurisdiction with his work in another. The closest Walsh comes to suggesting even an implicit link to the Soering decision is his statement that: ${ }^{81}$

Neither should our courts ignore the answerability of the State to the organs of the European Convention of Human Rights and Fundamental Freedoms if a fugitive offender is handed over to any other state, whether a member of the Council of Europe or not, where the courts are not satisfied that his treatment there would not be in breach of the rights protected by the Convention.

In any event, the "unarticulated euroskeptism" of the Irish Supreme Court, as Donncha O'Connell has termed it, ${ }^{82}$ or even a more generalised sense of antipathy towards international sources, served to bolster the steadfast view of the Irish courts that an unincorporated human rights treaty cannot form part of Irish law. On occasion the European Convention on Human Rights might have had a persuasive influence, prompting a thriving commentary throughout the 1980s and 1990s on the Convention's possible role within Irish proceedings, but the position of the Irish courts was nonetheless constitutionally respectful. Ireland's strict dualist approach to international law is in fact required by its Constitution, with Articles 15.2.1 ${ }^{\circ}$ and 29.6 vesting the "sole and exclusive power of making laws for the State" in the Oireachtas and providing expressly that "no international agreement shall be part of the domestic law of the State save as may be determined by the Oireachtas."

This remains the Irish position, although the status of the European Convention on Human Rights has now changed with the coming into force of the European Convention on Human Rights Act $2003,{ }^{83}$ which expressly enables further effect to be given to the Convention, as well as four of its substantive Protocols (Nos 2, 4, 6 and 7), within Irish law. Although this legislation does not incorporate the Convention directly into the Irish Constitution - a route recommended against by the Constitution Review Group in 1996 for fear it would diminish the protection afforded to personal

81 Finucane, above n 79, 217.

82 Donncha O'Connell "Ireland" in Robert Blackburn and Jorg Plokiewicz (eds) Fundamental Rights in Europe: The European Convention on Human Rights and its Member States 1953-2000 (Oxford University Press, Oxford, 2001) 428.

83 ECHR Act, above n 65. See further, Donncha O'Connell "The ECHR Act 2003: A Critical Perspective" and Gerard Hogan "Incorporation of the ECHR: Some Issues of Methodology and Process" in Ursula Kilkelly (ed) ECHR and Irish Law (Jordans, Dublin, 2004) 1-11 and 13-34. See also Ray Murphy "The Incorporation of the ECHR into Irish Domestic Law" (2001) 6 EHRLR 640 and Suzanne Egan "The European Convention on Human Rights Act 2003: A Missed Opportunity for Domestic Human Rights Litigation" (2003) 25 DULJ 230. 
rights $^{84}$ - it does incorporate the Convention at a sub-constitutional level, allowing the treaty (and its associated jurisprudence) to serve as a tool for interpretation ${ }^{85}$ and a guide for the performance of state functions. 86

It is a mode of incorporation similar to that embraced by the British HRA, and frankly, deliberately so, given the desire expressed within the Belfast Peace Agreement of $1998^{87}$ to ensure equivalent levels of protection for human rights in the north and south of Ireland. And like the British HRA, the Irish incorporation legislation provides an express mandate for the judicial consideration of European decisions to ensure that "due account" is taken of the principles laid down within. ${ }^{88}$ While there is, as yet, no case law discussing the nature of this "judicial notice" obligation, some may be forthcoming given the Irish High Court's dismissal of an attempt by Ryanair to have struck out a claim by its pilots' union in which the domestic impact (and correct interpretation) of a European judgment concerning the Convention right to freedom of association will play a crucial part. ${ }^{89}$

\section{THE ABSENT OBLIGATION TO CONSIDER INTERNATIONAL CASE LAW}

Following the enactment of the Canada Act 1982, Canada's constitutional order gained an entrenched bill of rights known as the Canadian Charter of Rights and Freedoms. As a component of the Constitution of Canada, the Charter is part of Canada's supreme law and "any law that is inconsistent with the provisions of the Constitution is, to the extent of the inconsistency, of no force or effect." ${ }^{90}$ As with other bills of rights, the Charter restricts the government's ability to infringe certain human rights guarantees, although these guarantees are not absolute. A general limitation clause, found in section 1 of the Charter, makes it clear that all Charter rights are "subject only to such reasonable limits prescribed by law as can be demonstrably justified in a free and democratic society," thus authorising the weighing of individual rights against competing community interests according to a balancing test named after the well-known case of Oakes. ${ }^{91}$

84 Report of the Constitution Review Group, above n 72. The Group recommended what is termed "à la carte" incorporation - a form favouring reliance on the Convention only where the protection offered by the Irish Constitution could be improved.

85

86

87

88

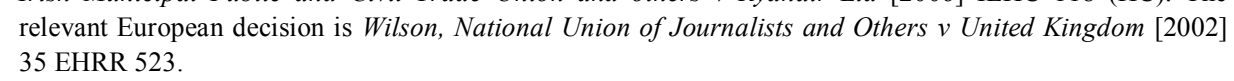
relevant European decision is Wilson, National Union of Journalists and Others $v$ United Kingdom [2002] 35 EHRR 523.

90

91

ECHR Act, s 2(1).

ECHR Act, s 3(1).

Agreement Reached in the Multi-Party Negotiations (10 April 1998) [2000] Ir TS 18.

ECHR Act, s 4 .

Constitution Act, 1982, s 52(1), being Schedule B to the Canada Act 1982, c 11 (UK).

Oakes, above n 74 . 
But the domestic importance of Canada's Charter does not mean that it should be viewed in a vacuum. As a codification of human rights guarantees viewed as fundamental, the Charter clearly has an international heritage, with its provisions having been influenced, if not borrowed, from preceding human rights treaties, including the International Covenant on Civil and Political Rights, ${ }^{92}$ to which Canada had become bound just six years prior. The rights protected by the Covenant, including those to life, liberty and humane treatment, the rights to equality and a fair trial, and the freedoms of expression, religion and assembly are all rights protected within Canada by the Charter, although in some cases with less specificity. While the Charter does not expressly incorporate the Covenant into domestic law, and thus contains no express obligation to consider either its terms or its associated jurisprudence, Canada's periodic reports to the treaty's monitoring body, the UN Human Rights Committee, clearly show that Canada relies on the Charter to meet its Covenant obligations.

And yet Canadian case law reveals surprisingly few references to Canada's obligations under the Covenant, let alone their interpretation by the Human Rights Committee in concrete cases of alleged violation. A passing reference is made by the Supreme Court of Canada to several Committee views in the child-spanking case of Canadian Foundation for Children, Youth and the Law v AttorneyGeneral (Canada), ${ }^{93}$ but the Court does not even provide the case names, thus treating the Committee's views as just another UN report. A better example of a Supreme Court citation of, and engagement with, a Committee view is found in the hate speech case of $R v$ Keegstra, ${ }^{94}$ but this case was decided in 1990, leaving over a decade of silence in the "dialogue" embraced by Justice L'Heureux-Dubé. ${ }^{95}$ Such silence stands in contrast with the Court's apparent openness to citing European jurisprudence, which of course has no formal link to Canada. Is it the absence of an express obligation or legislative mandate to consider the views of the international body charged with monitoring Canada's compliance with its human rights treaty obligations that accounts for this silence? Or are Canadian judges choosing not to "communicate" with the members of the UN Human Rights Committee for some other reason?

If the reason is one of disagreement with the views of the UN Human Rights Committee, or a lack of confidence in its reasoning, then a citation saying so may well serve to improve the output of the Human Rights Committee. Committee decisions, such as that in the deportation case of Judge v

92 International Covenant on Civil and Political Rights (16 December 1966) 999 UNTS 171; (1967) 6 ILM 368; Can TS 1976 No 47 (in force 23 March 1976).

93 Canadian Foundation for Children, Youth and the Law v Attorney-General (Canada) [2004] 1 SCR 76, para 33.

$94 R v$ Keegstra [1990] 3 SCR 697, paras 70, 211.

95 L'Heureux-Dubé, above n 1. 
Canada, ${ }^{96}$ clearly show that the international body is receptive to the consideration of the domestic case law of the state against which the complaint is made, with the Committee in Judge citing the Supreme Court of Canada's decision in United States $v$ Burns ${ }^{97}$ to bolster the conclusion that there is a broadening international consensus in favour of the abolition of the death penalty. And yet the Supreme Court of Canada, despite its citation to a litany of international sources in Burns, makes no mention of the Committee's decisions in the clearly related cases of Kindler v Canada and $\mathrm{Ng} v$ Canada, both of which proceeded from the Canadian national arena to the international plane. ${ }^{98} \mathrm{By}$ contrast, both the domestic and international decisions in Kindler and $\mathrm{Ng}$ have been cited by the South African Constitutional Court. ${ }^{99}$ The Committee's views in Kindler have also been cited by the New Zealand Supreme Court. ${ }^{100}$

Like Canada, New Zealand lacks an express obligation in its domestic law to consider the decisions of an international tribunal to which New Zealand is linked by treaty. But unlike Canada, the New Zealand courts seem to have found an implied mandate to consider the Covenant and its associated jurisprudence within the preamble to the New Zealand Bill of Rights Act 1990, which clearly states that one of the Act's purposes is "to affirm New Zealand's commitment to the International Covenant on Civil and Political Rights." As a result, one can find references to Human Rights Committee decisions in New Zealand judgments. ${ }^{101}$ However, as in South Africa and the United Kingdom, when interpreting a New Zealand law, even one intended to incorporate New Zealand's international obligations into domestic law, the New Zealand courts are not bound to adopt the interpretations offered by the Human Rights Committee. Instead, the Committee's decisions are considered by the New Zealand courts to be of "considerable persuasive authority". 102

96 Judge v Canada (5 August 2003) CCPR/C/78/D/829/1998 (UNHRC) in "Report of the Human Rights Committee"(1 November 2003) A/58/40 (vol II) 76; reprinted in (2003) 42 ILM 1214; (2004) 11 IHRR 125.

97 United States v Burns [2001] 1 SCR 283.

98 See Kindler v Canada (30 July 1993) CCPR/C/48/D/470/1991 (UNHRC) in "Report of the Human Rights Committee" (1 November 1993) A/48/40 (vol II) 138; reprinted in 98 ILR 426, (1993) 14 Hum Rts LJ 307, (1994) 1 IHRR 98; $N g$ v Canada (5 November 1993) CCPR/C/49/D/469/1991 in "Report of the Human Rights Committee" (21 September 1994) A/49/40 (vol II) 189, reprinted in 98 ILR 479, (1994) 15 Hum Rts LJ 149, (1994) 1 IHRR 161.

99 Makwanyane, above n 30, paras 63-67.

100 Zaoui v Attorney-General (No 2) [2006] 1 NZLR 289, para 79 (SC) Keith J for the Court.

101 Ibid. See also Zaoui v Attorney-General [2005] 1 NZLR 577, paras 94-96 (CA) McGrath J.

102 See $R v$ Goodwin (No 2) [1993] 2 NZLR 390, 393 (CA) Cooke P for the Court and Nicholls $v$ Registrar of the Court of Appeal [1998] 2 NZLR 385, 404 (CA) Eichelbaum CJ. See further, Paul Rishworth and others The New Zealand Bill of Rights (Oxford University Press, Oxford, 2003) 11-16. 


\section{CONCLUSION}

The ratification and then incorporation into domestic law of an international human rights treaty raises several democratic dilemmas. By their very nature, international human rights treaties are intended to create lasting legal regimes that adapt over time to meet changing realities and contemporary mores. Yet their constantly evolving nature can also challenge the democratic underpinnings of a state's acceptance of their obligations, particularly when a treaty's current interpretation at the international level is one to which the state's domestic organs would have never given their consent twenty or thirty years prior. In such circumstances, withdrawal may seem the only democratic option for the state concerned.

Yet, while the bluntness of such an approach offers domestic clarity, other states have embraced a more subtle approach in their attempts to address the democratic implications that inevitably arise from the ratification, and then implementation, of a human rights treaty. The means chosen to incorporate the European Convention on Human Rights into the domestic law of both Ireland and the United Kingdom provide a recent example, as does South Africa's experience with constitutionally-required consideration of international and foreign law. In essence, these states have opted for a more subtle form of treaty incorporation that requires their domestic authorities to "take into account" the human rights treaty and its evolving interpretations, whether positive or negative, but all stop short of making the obligations and jurisprudence automatically binding under domestic law.

Some may complain that this method of reconciling a state's international commitments with its domestic law is weak, ineffective, or possibly disingenuous with respect to the protection of universal human rights guarantees. But it is likely the most democratic means of incorporation since to do otherwise would give an international body the power to determine the domestic meaning of what have become domestic rights. This indirect method of domestic incorporation, and the dialogue it entails, is also more in keeping with the democratic underpinnings of the treaty itself, given the degree of variance, or "margin of appreciation", allowed by international human rights treaties with respect to the domestic implementation of their obligations, at least in areas where a consensus in interpretation has yet to be achieved. Canada's dilemma is that it is more like the United States than many are willing to acknowledge, with its constitution lacking the imperative to consider international law, including the interpretation of that law by its associated international tribunals. 
